\title{
Web-Based Competency Test Model for Midwifery Students
}

\author{
Andi Wilda Arianggara \\ Midwifery Studies Program, Post Graduate School, Hasanuddin University, Indonesia \\ Corresponding Email: arianggaraaw19@student.unhas.ac.id
}

\author{
Yusring Sanusi Baso \\ Learning Media Center, Learning Resources and E-Learning, Hasanuddin University, Indonesia \\ Email: yusring@unhas.ac.id
}

\author{
Sri Ramadany \\ Department of Community Medical Science, Faculty of Medicine, Hasanuddin University, Indonesia \\ Email: sriramadanifk@gmail.com
}

Esther Sanda Manapa

Graduate School, Hasanuddin University, Indonesia

Email: esmanapa@gmail.com

\author{
Andi Nilawati Usman \\ Post Graduate School, Hasanuddin University, Indonesia \\ Email: andinilawati@pasca.unhas.ac.id
}

\begin{abstract}
This study aims to find out (1) the feasibility of the web-based competency test model, and (2) the effectiveness of the web-based competency test model towards increasing the confidence of midwifery students in facing the competency test. Research method using Research and Development $(R \& D)$ and Pre-Experiment One Group Pretest-Posttest with Purposive Sampling Technique which is as many as 45 samples. This research was conducted in the Polytechnic of Health Ministry of Makassar and Megarezky University in November 2020. The data is analyzed using statistical analysis by Wilcoxon Test. Validation test results from media experts averaged 87.9\% and validation results from material experts averaged $94 \%$ which showed that web competency test model applications are very feasible to use. User validation average feasibility score of $87 \%$ of the data showed that the application of web-based competency test model is very feasible to use. The results of the effective use of web-based competency test models found that the Wilcoxon Test obtained a p-value of $0.00<0.05$. So it can be concluded that the Web-based competency test model is feasible and effective in increasing student confidence facing the competency test.
\end{abstract}

Keywords---confidence, effectiveness, feasibility, midwifery, web-based competency test model.

\section{Introduction}

Competency Test is a form of self-evaluation of students and universities in improving the education process, quality assurance of graduates, implementation of curriculum, and sharpening the relevance of competencies following competency standards desired by professions and service users (Delavari et al., 2018; Ministry of Education, 2020; Ministry of Research and Technology, 2019). Competency Test is organized by universities in collaboration with Midwives Professional Organization, health worker training institutions, or accredited health professional certification bodies. Competency Test holds $40 \%$ of the proportion of assessments that become one of the requirements for vocational education and professional education graduation (Ministry of Education, 2020; Ministry of Research and Technology, 2019). 
Institutions have a very important role in student graduation in taking competency tests. Therefore, institutions are required to use various methods to increase student graduation in competency tests (Mushawwir et al., 2020). Some of the strategies undertaken by the institution to increase student graduation in competency tests include; online caching, nursing clinic courses, remedial policies, fourteen steps exit examination review, a course focusing on solving clinical decision problems, preparation competency test courses, course work, and adaptive quizzing system tests, the educational basic curriculum establishment, learning methods, the students risk adaptive quizzing program detection, learning style, confidence and Locus of Control (LOC) as some strategy of the institution to improve student passing grade in competence exam (Mushawwir et al., 2019). New strategies have emerged for universities and students to face the Competency Test, one of which is by participating in the Try Out Competency Test. Try out is a method to visualize the true state of the exam and become a place for students to practice before facing the real exam. Try Out method can help students get good test scores and of course be ready and confident in facing the Competency Test (Farisi et al., 2017; Rohaendi, 2019; Hifza, 2020; Hifza et al., 2020; Rachmawati et al., 2020).

The transition of the competency test implementation system from Paper-Based Test (PBT) to Computer Based Test (CBT) becomes a new challenge for universities. This can lead to a decrease in student confidence to face competency tests, especially for students who have limitations in learning, the number of stressors when nearing the end of education, and not used computer-based test methods. Therefore, learning media is needed that can support this. One of them is a web learning media developed into a Web-Based Competency Test Model that students can use to try out competency tests (Embryol, 2014; Geraili-Afra et al., 2018; Kumar et al., 2019; Reid et al., 2016).

Web-based learning media is one of the web-based education services that enable edutainment by using internet media. E-learning significantly affects the education system. Supported by the development of information systems and an adequate internet network so that e-learning currently has great potential to be realized. E-learning is the latest trend in the world of education because its use can exceed the limits of space and time, it is not uncommon for electronic-based learning to be assessed up to date. The existence of the internet enables distance learning that not only transmits information but creates a real-time learning environment. One form of internet network use in distance learning is the creation of web-based learning (Dame Tina Lavender et al., 2013; Januarisman \& Ghufron, 2016; Liu et al., 2016; Margolis et al., 2009; Wang \& Chen, 2010).

Based on the needs analysis that has been done by researchers at the Midwifery Student Level III Polytechnic of Health Ministry of Makassar. 11 respondents obtained (100\%) who assume that this Web-Based Competency Test Model is urgently needed to support the learning process and assist in problem analysis (63.6\%). Respondents' expectation of the web-based competency test model that is being designed is to improve students' skills in analyzing questions, helping students in time management answering questions (One Minute One Question), can measure students' ability by displaying scores shortly after the exam is completed and can make students ready and confident in facing the Competency Test. The results of the analysis are in line with several research results that show that the test method using the computer (Computer Based Test) is easier to use and more users friendly (Polytechnic of Health Ministry of Makassar, 2020; Reid et al., 2016).

Based on the above ideas, researchers have the idea that to increase student confidence, appropriate learning media is needed and following the characteristics of student learning, namely digital learning. Web-Based Competency Test Model is an innovation in learning media that can increase student confidence in facing a competency test. Therefore, researchers want to design and develop a Web-Based Competency Test Model in Midwifery Students (Harvey et al., 2002; Pallant et al., 2015).

\section{Research Methods}

This research will use the Combination Method between research and development ( $\& \mathrm{D})$ and Pre-Experimental One Group Pretest-Posttest method. R \& D method used to produce products and methods Pre-Experimental One Group Pretest-Posttest is used to test the effectiveness of the product created (web-based competency test model in midwifery students) in increasing student confidence facing competency test (Baso, 2016). This research was conducted in the Polytechnic of Health Ministry of Makassar and Megarezky University. Samples in this study are 48 students of Polytechnic of Health Ministry of Makassar and 12 students of Megarezky University. 
Results

Figure 1 Web-Based Competency Test Model View

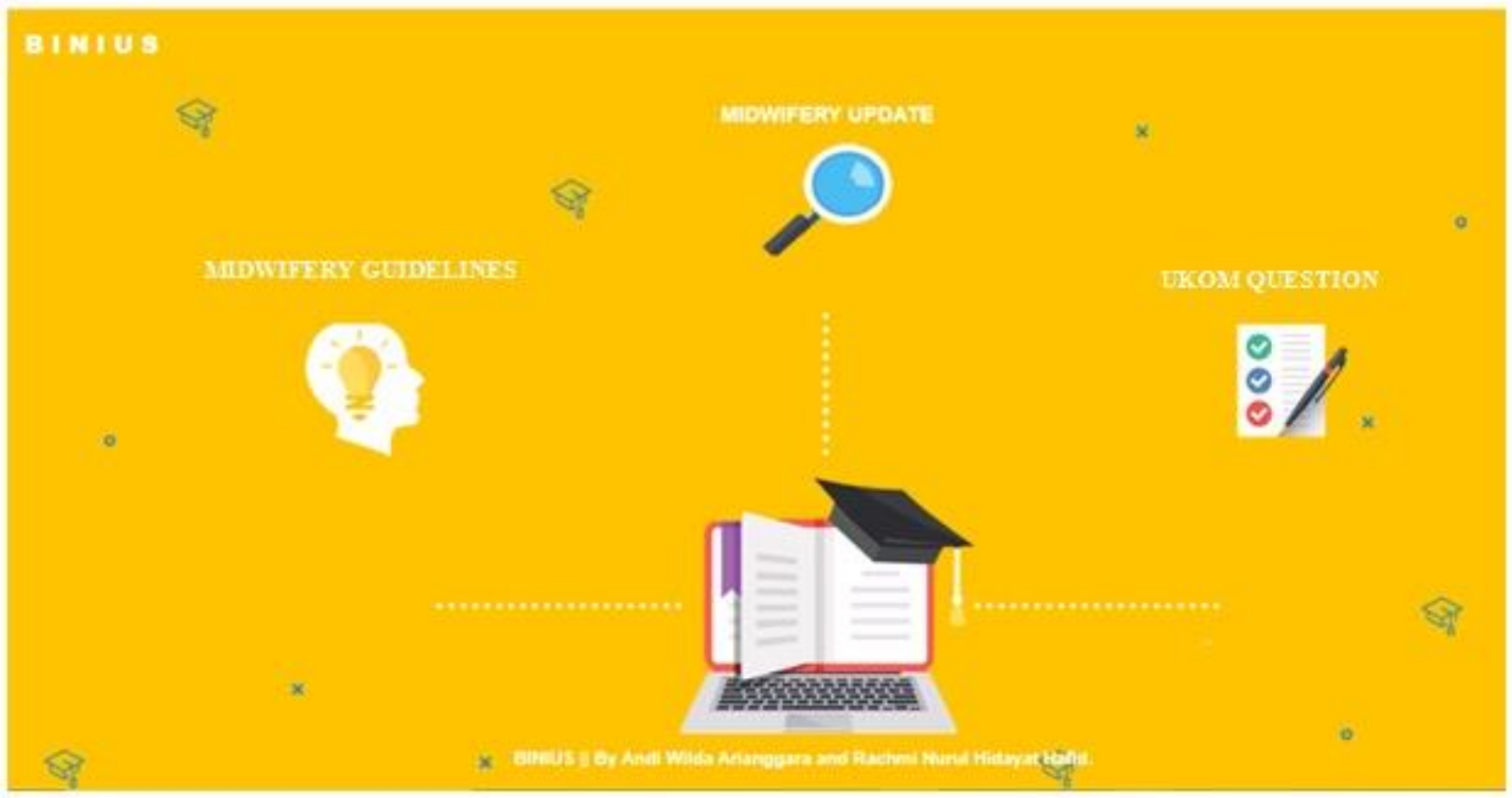

Figure 1. Is a display of the web-based competency test model as a web learning media that can increase students' confidence in facing the competency test

Product validation is carried out to see the feasibility of a web-based competency test model. Data obtained from the results of filling instruments in the form of questionnaires. Here are the validation test results of media experts and material experts:

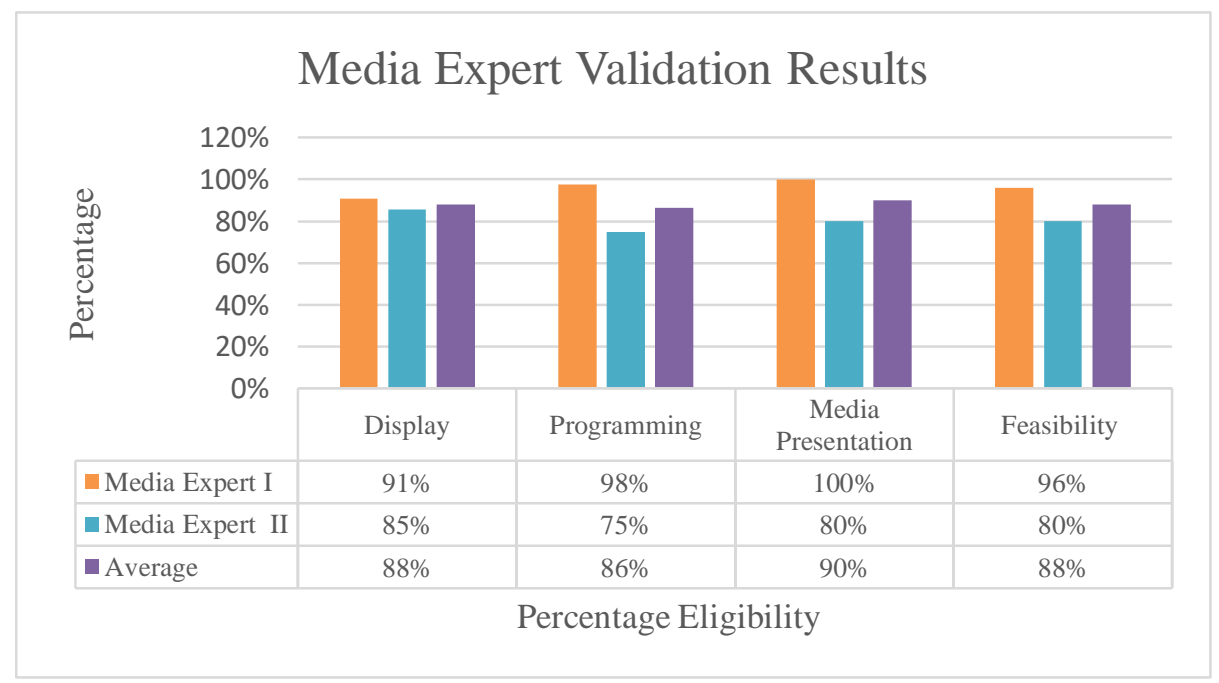

Graph 1. Results of media expert validation on web-based competency test model 


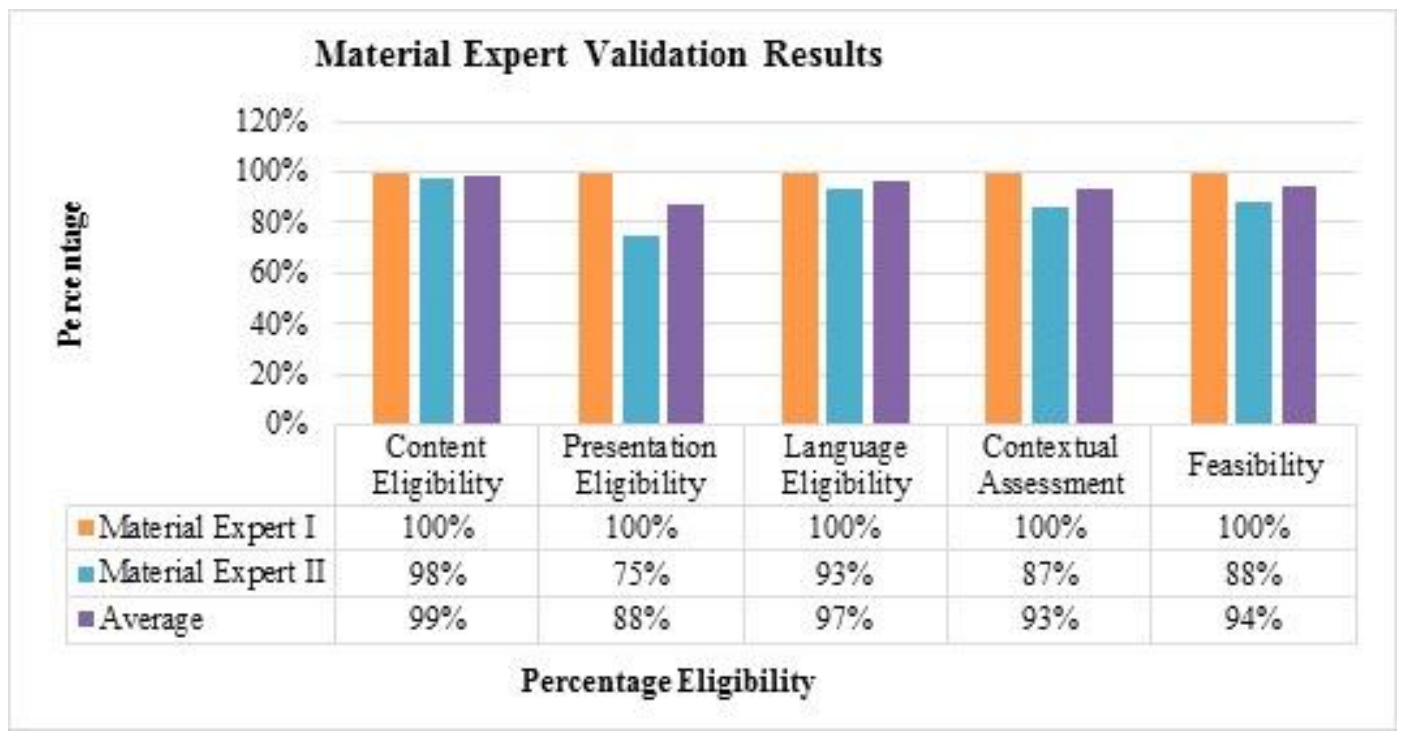

Graph 2. Results of material expert validation on web-based competency test model

User validation data was obtained through the filling of research instruments in the form of TAM (Technology Acceptance Model) questionnaires. Here are the results of the small group and large group user validation tests:

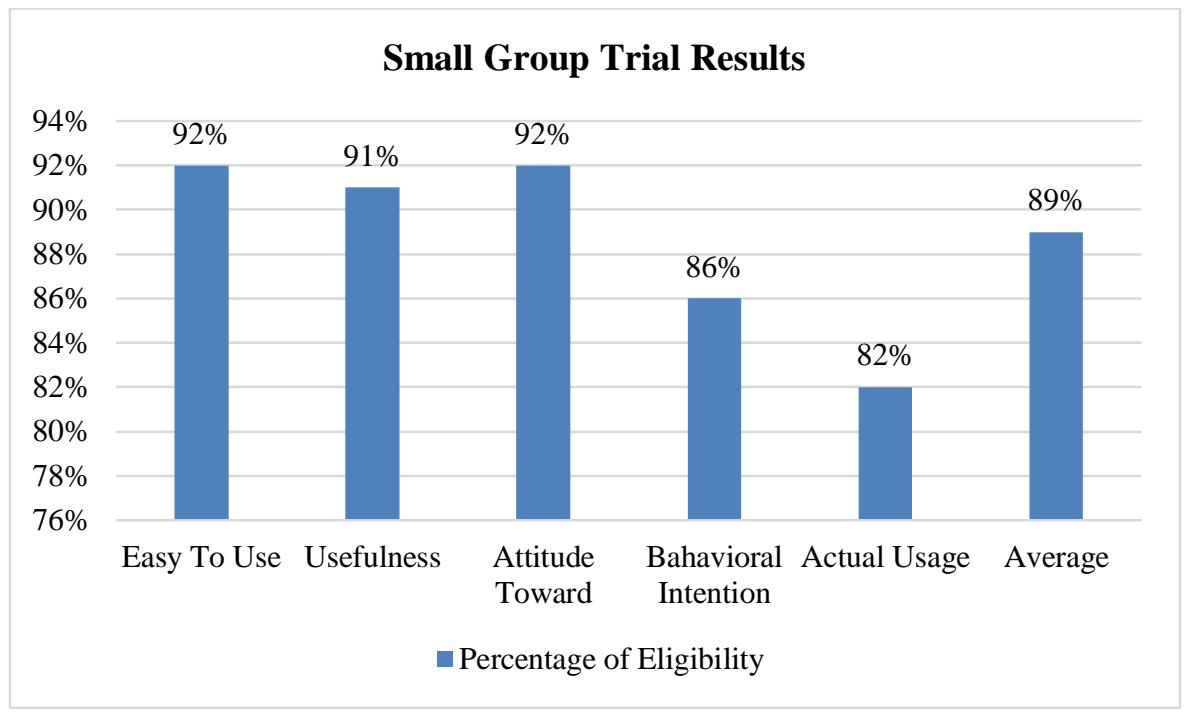

Graph 3. Results of user validation (small group) 


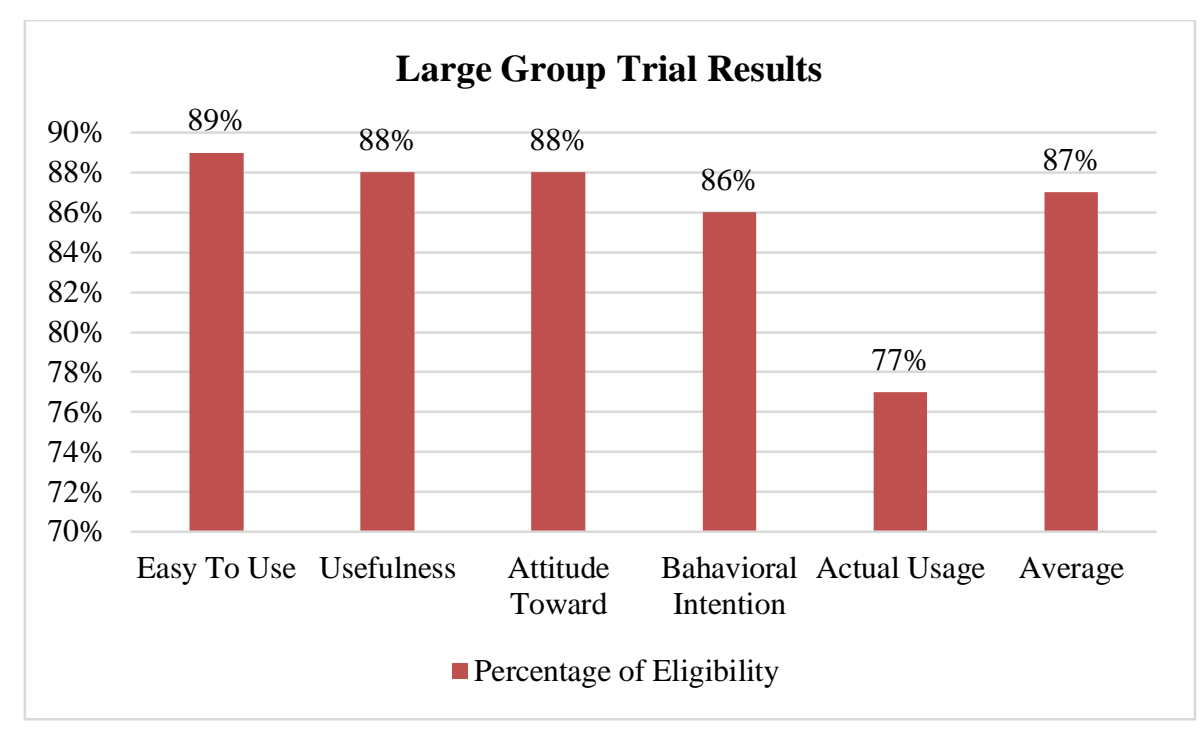

Graph 4. Results of User Validation (Large Group)

Of the overall assessment results conducted by media experts, material experts, as well as users (small and large groups) web-based competency test models are feasible to use with an average feasibility value of media experts $(88 \%)$, material experts (94\%), small group users (89\%), and large group users (87\%). Furthermore, to test the effectiveness of the web-based competency test model conducted Wilcoxon Sign Rank Test, with the following results:

Table 1

Results of student self-confidence test on effectiveness of web-based competency test model

\begin{tabular}{llll}
\hline & Mean & Minimum - Maximum & P-Value \\
\hline Pretest $(n=45)$ & 78.11 & $63-93$ & 0,000 \\
Posttest $(n=45)$ & 83.67 & $69-100$ & \\
\hline
\end{tabular}

The table above shows the pretest average score of 78.11, rounded to $78 \%$ in the high confidence category, after learning using a web-based competency test model confidence in students increased to 83.67 rounded to $84 \%$ in the high confidence category. Meanwhile, the p-value significance result of $0.000<0.05$ can be concluded that the webbased competency test module is effective in increasing student confidence in facing the competency test.

\section{Discussion}

The results of the Web-Based Competency Test Model for Midwifery Students can be found in Graphs 1, 2, 3, and 4. Based on graph 1, the percentage of media expert validation test results against web-based Competency Test Model is $88 \%$, graph 2 shows that the percentage of material expert validation test results is $94 \%$, graphs 3 and 4 show that the results of user validation tests using TAM (Technology Acceptance Model) questionnaires, components that include perceived ease to use, perceived usefulness, attitude toward, behavioral intention and actual usage with very decent categories. Some research states that user acceptance of information technology innovation is done by TAM analysis because the user's intention to use the new information system can be influenced by the perception of whether a system will be useful and easy to use (Udayanti \& Nugroho, 2018; Ammenwerth, 2019). The percentage of feasibility results by TAM questionnaires in small groups is $89 \%$ and in large groups is $87 \%$. All four feasibility percentages indicate that the web-based competency test model is well worth using (Wibawa \& Wiksuana, 2019).

The results of the effectiveness test model of web-based competency test in increasing student confidence can be seen in table 1. Table 1 shows that the average pretest score of students is 78.11 with high confidence category and posttest value i.e. after using web-based competency test model is 83.67 with very high confidence category. Both 
data showed an increase in value after the intervention in the form of providing a web-based competency test model. Furthermore, the significance test of the difference in an average increase in pretest and posttest score by using Wilcoxon Sign Rank Test with p-value significance result of $0.00<0.05$ then it can be concluded that web-based competency test module is effective in increasing student confidence in facing midwifery competency test. These results are in line with research conducted by Van den Boom et al., (2004), this study aims to test the influence of web quest methods and team-based learning. This research was conducted by intervening in the form of web quests for two years in a row and other groups were taught using team learning. The results showed that web defense can change student self-control and self-management to improve student self-regulation. Web-based learning media has high effectiveness as support in student learning this is in line with Chiu \& Wang (2008). This study aimed to assess the effectiveness of web-based PBL (Problem Based Learning), involving 162 experimental groups using web-based learning approaches and 166 control groups using conventional learning approaches. With the following research results: student test scores and self-learning ability were significantly higher in the experimental group ( $<<00.1)$. Also, $92.6 \%$ of students in the experimental group expressed satisfaction with web learning methods. These results demonstrate the effectiveness of web-based teaching technologies in problem-based learning (Ding \& Zhang, 2018; Jahromi et al., 2016).

\section{Conclusion}

Based on the results of validation tests conducted by media experts, material experts, and users, the Web-Based Competency Test Model is very feasible to use and based on the test results obtained an increase in the value of pretest-posttest after the intervention, the use of Web-Based Competency Test Model is effective in increasing the confidence of students in facing the midwifery competency test.

\section{Acknowledgments}

We thank our mentors, our parents, and the Polytechnic of Health Ministry of Makassarand Megarezky University for the support and assistance provided during our research and special appreciation to all study participants who volunteered for this research.

\section{References}

Ammenwerth, E. (2019). Technology Acceptance Models in Health Informatics: TAM and UTAUT. Studies in health technology and informatics, 263, 64-71.

Baso, Y. S. (2016). Model Pembelajaran Bahasa Arab Online Berbasis Learning Management System. Makassar: Program Studi Sastra Arab Universitas Hasanuddin.

Chiu, C. M., \& Wang, E. T. (2008). Understanding Web-based learning continuance intention: The role of subjective task value. Information \& Management, 45(3), 194-201. https://doi.org/10.1016/j.im.2008.02.003

Delavari, S., Amini, M., Sohrabi, Z., Koohestani, H., Delavari, S., Rezaee, R., ... \& Kheirkha, M. (2018). Development and psychometrics of script concordance test (SCT) in midwifery. Medical journal of the Islamic Republic of Iran, 32, 75.

Ding, Y., \& Zhang, P. (2018). Practice and effectiveness of web-based problem-based learning approach in a large class-size system: A comparative study. Nurse education in practice,31, 161-164. https://doi.org/10.1016/j.nepr.2018.06.009

Embryol, R. J. M. (2014). Doctoral and post-doctoral research-a priority of the Romanian postgraduate education system (Doc-Postdoc). Rom J Morphol Embryol, 55(4), 1531-1532.

Farisi, SA, Ramdlani, S., \& Haripradianto, T. (2017). Optimizing the Green Open Space Function in the City Forest Complex at the Sawojajar Velodrome. Journal of Architecture Department Students , 5 (2).

Geraili-Afra, Z., Abadi, A., Yazdani-Charati, J., Gooraji, S. A., Zarghami, M., \& Saadat, S. (2018). Comparison of Efficiency GEE and QIF Methods for Predicting Factors Affecting on Bipolar I Disorder Under Complete-case in a Longitudinal Studies. Acta Informatica Medica, 26(2), 111.

Harvey, S., Rach, D., Stainton, M. C., Jarrell, J., \& Brant, R. (2002). Evaluation of satisfaction with midwifery care. Midwifery, 18(4), 260-267. https://doi.org/10.1054/midw.2002.0317

Health Politechnic of Makassar. (2020). Results of Analysis of Needs of Web-Based Competency Test Model.

Hifza, A. (2020, June). The Model of Competitive Advantage Development in Private Islamic Education Institutions. In BASA 2019: Proceedings of the Third International Seminar on Recent Language, Literature, and Local 
Culture Studies, BASA, 20-21 September 2019, Surakarta, Central Java, Indonesia (p. 205). European Alliance for Innovation.

Hifza, J., Palapa, A., \& Maskur, A. (2020). The Strategic Foundation for Competitive Excellent Development in Integrated Islamic Primary Schools in Indonesia.

Jahromi, Z. B., Mosalanejad, L., \& Rezaee, R. (2016). The effect of web quest and team-based learning on students' self-regulation. Journal of advances in medical education \& professionalism, 4(2), 80.

Januarisman, E., \& Ghufron, A. (2016). Development of web-based learning media for natural science subjects for grade VII students. Journal of Educational Technology Innovation, 3 (2), 166-182.

Kumar, B., Shah, M. A. A., Kumari, R., Kumar, A., Kumar, J., \& Tahir, A. (2019). Depression, anxiety, and stress among final-year medical students. Cureus, 11(3).

Lavender, D. T., Omoni, G., Lee, K., Wakasiaki, S., Campbell, M., Watiti, J., \& Mathai, M. (2013). A pilot quasiexperimental study to determine the feasibility of implementing a partograph e-learning tool for student midwife training in Nairobi. Midwifery, 29(8), 876-884. https://doi.org/10.1016/j.midw.2012.10.003

Liu, Q., Peng, W., Zhang, F., Hu, R., Li, Y., \& Yan, W. (2016). The effectiveness of blended learning in health professions: systematic review and meta-analysis. Journal of medical Internet research, 18(1), e2.

Margolis, L. M., Grediagin, A., Koenig, C., \& Sanders, L. F. (2009). Effectiveness and acceptance of web-based learning compared to traditional face-to-face learning for performance nutrition education. Military medicine, 174(10), 1095-1099.

Ministry of Education. (2020). National Competency Test of Health Workers Education Program.

Ministry of Reseach and Technology. (2019). National Competency Test Participant Preparation Guide.

Mushawwir, A., Tahir, T., Kadar, K., \& Saragih, S. L. (2020). Evaluate the Implementation of Educational Curriculum and Lecturer's Knowledge About the Blueprint to the UKNI's Graduation Rate in South Sulawesi. Int. J. Psychosoc. Rehabil, 24(08), 14709-14719.

Mushawwir, A., Tahir, T., Kadar, K., Ahmar, H., \& Khalid, N. (2019). Gambaran Strategi Program Studi Keperawatan Untuk Meningkatkan Kelulusan Mahasiswa Dalam Uji Kompetensi: Literatur Review. Jurnal Keperawatan Muhammadiyah, 4(2).

Pallant, J. F., Dixon, L., Sidebotham, M., \& Fenwick, J. (2015). Further validation of the perceptions of empowerment in midwifery scale. Midwifery, 31(10), 941-945. https://doi.org/10.1016/j.midw.2015.05.008

Rachmawati, M., Widjajanti, S., Ahmad, A., \& Aslan, A. (2020). The English Camps as Method of Promoting Fun English at Elementary School Level in Indonesia. Tapis: Jurnal Penelitian Ilmiah, 4(2), 174-182.

Reid, J., Robinson, D., \& Lewis, C. (2016). Assess-ing the evidence: student response system versus computer based test-ing for undertaking multiple choice question assessment in undergradu-ate nursing education. Pediatr Neonatal Nurs Open J, 3(1), 10-14.

Rohaendi, N. (2019). Attempts To Improve The Mathematical Communication Skills Of Class Vb Students Of Sdn 074 Ayudia Kota Bandung In Data Processing Materials Through The Tutor-Assisted Scientific Approach. (JIML) Journal Of Innovative Mathematics Learning, 2(3), 96-103.

The Minister of Education. (2020). Permendikbud No. 02 Year 2020 on Procedures for Implementation of Student Competency Test in health sector. https://lldikti11.ristekdikti.go.id/download/peraturan-menteri-pendidikan-dankebudayaan-republik-indonesia-nomor-2-tahun-2020-tentang-tata-cara-pelaksanaan-uji-kompetensi-mahasiswabidang-kesehatan.

Udayanti, E. D., \& Nugroho, F. A. (2018). Analisa Minat Penggunaan Aplikasi TB eScoring dengan Pendekatan Technology Acceptance Model (TAM). Edu Komputika Journal, 5(1), 1-12.

Van den Boom, G., Paas, F., Van Merrienboer, J. J., \& Van Gog, T. (2004). Reflection prompts and tutor feedback in a web-based learning environment: Effects on students' self-regulated learning competence. Computers in Human Behavior, 20(4), 551-567. https://doi.org/10.1016/j.chb.2003.10.001

Wang J, C. H. (2010). Application and comparation between vacuum extraction and obstetric forceps delivery. Chinese J PracGynecol Obstetrics, 11: 829e31.

Wang, J., \& Chen, H. (2010). A comparison of vacuum extraction and forceps delivery. Chinese Journal of Practical Gynecology and Obstetrics, 26(11), 829-831.

Wibawa, I. M. A. Y., \& Wiksuana, I. G. B. (2019). Performance analysis of pharmaceutical in stallation as basic of feasibility: a self-based business unit into general services agency. International research journal of management, IT and social sciences, 6(6), 229-238. 